\title{
Influence of Harvesting Methods and Timings on Yield and Quality of Selected Bread Wheat Varieties
}

\author{
Muhammad Mithal Lund ${ }^{1 a}$, Muhammad Ibrahim Keerio ${ }^{2}$, Shamsuddin Tunio ${ }^{1 b}$, \\ Allah Wadhayo Gandahi ${ }^{3 a}$, Inayatullah Rajpar ${ }^{3 b}$
}

RECEIVED ON 27.11.2018, ACCEPTED ON 19.05.2020

\begin{abstract}
An experiment was executed at experimental farm of Sindh Agriculture University Tandojam to quantify the losses in grain yield and quality of wheat in relation to time and method of harvesting. The experiment involved three bread wheat varieties (Kiran-95, Mehran-89 and TD-1) and two harvesting methods; conventional method using Sickle and mechanized method using Reaper. The harvesting times considered were: 5-days-before-maturity (DBM), 5-Days-after-maturity (DAM), 10 DAM, and 15 DAM. The data were recorded for grain yield, yield components (harvest index, seed index, etc.) and some grain quality traits (shriveled \& broken grain losses). The results highlighted that, harvesting with reaper was most effective and economical in terms of losses to grain yield and quality over sickle (manual) method of harvesting. Compared to the other harvesting times tested in this study, the wheat crop harvested at proper physiological maturity (5 DAM) was found to be most effective and beneficial to maintain quality and obtain maximum grain yield. Generally, wheat crop harvested through conventional method using sickle showed more harvesting losses at different harvesting intervals. Among three wheat cultivars, the cultivar TD-1 harvested with sickle (manual method) at proper maturity, 5 DBM and 5, 10 and 15 DAM showed 5.55\%, 6.54\%, 7.09\%, 8.06\% and $9.45 \%$ harvesting losses; and $8.79 \%, 10.46 \%, 10.67 \%, 11.76 \%$ and $13.25 \%$ hauling losses, respectively. Contrarily, when same cultivar TD-1 was harvested through mechanized method using reaper, the respective treatment plots showed 5.35\%, 6.09\%, 6.21\%, 7.07\% and 8.49\% harvesting losses, and $8.57 \%, 9.89 \%, 9.54 \%, 10.45 \%$ and $11.99 \%$ hauling losses to grain yield, respectively. This study suggests that wheat crop should be harvested with reaper at proper physiological maturity. Among the three bread wheat varieties included in the study, the variety Kiran-95 proved to be the most resistant to grain yield and quality losses.
\end{abstract}

Keywords: Bread Wheat, Grain Yield and Quality, Harvesting Methods and Timing

\section{INTRODUCTION}

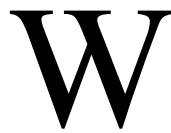

orld population is estimated to reach or cross 10.5 billion till 2050 [1]. One of the greatest challenges faced by modern agriculture is of food insecurity [2-3]. Therefore the global food production must be enhanced up to $60 \%$ by 2050 , in order to fulfill the food requirements of $33 \%$ increase in world population [4]. Post-harvest losses accounts for about $1 / 3$ of agriculture production loss yearly across the globe, and this contribute widely towards insecurity of food [5]. However, post-harvest

${ }^{1}$ Department of Agronomy, Sindh Agriculture University, Tando Jam, Sindh, Pakistan.

Email: ${ }^{1 a}$ muhammadmithal130@gmail.com (Corresponding Author), ${ }^{\text {b }}$ sd tunio@hotmail.com

${ }^{2}$ Department of Crop Physiology, Sindh Agriculture University Tando Jam, Sindh, Pakistan. Email: mikeerio@gmail.com

${ }^{3}$ Department of Soil Science, Sindh Agriculture University, Tando Jam, Sindh, Pakistan. Email: ${ }^{3 a}$ gandahi@yahoo.com, 3birajpar@yahoo.com

This is an open access article published by Mehran University of Engineering and Technology, Jamshoro, under CC BY 4.0 International License. 
losses are not paid much attention in terms of allocation of resources [6]. In last 30 years, about $95 \%$ of the investment has been made on enhancing yield; whereas only $5 \%$ was used for minimizing postharvest losses [7]. Minimizing the post-harvest losses has been found to increase the availability and access to food and reduction in global food insecurity [8]. Substantial reduction in post-harvest losses has also been associated with food security, particularly by raising the income of growers [9]. In addition, crop production contributes significant proportion of typical income (70\% in Sub-Saharan Africa) and reduction in food loss can ultimately enhance the income of the producers. Wheat significantly contributes towards world food supply by providing energy, proteins, fats, minerals and vitamins. Wheat as a staple food is responsible for $20 \%$ food calories of the world. It contains $70 \%$ carbohydrate, $12 \%$ water and protein, $2.20 \%$ crude fiber, $2 \%$ fat and about $1.80 \%$ minerals and straw which is used as feed for animals and for industrial products [10]. Globally, wheat ranks $3^{\text {rd }}$ in overall cereal production (after maize and rice) and the crop is widely consumed as human food grain [11]. Cereal grains including wheat, oat, rice, barley and maize are enriched with proteins. The proteins supplied by wheat are much nutritious than the proteins supplied by other food products [12]. Proteins are principal components of all living cells and are involved in structure and activities of cell. A series of farm field operations (harvesting, threshing, winnowing, bagging, transportation, storage, processing, exchange, etc.) is required to produce agricultural commodities. Considerable losses occur in crop output at all these stages [13]. Both quantitative and qualitative losses occur. Quantitative loss can easily be determined physically by recording weight or volume, whereas deterioration in quality can only be assessed. Harvest losses to grains start with reaping of crop, mostly caused by shattering. While the postharvest losses are mainly caused by farm labor involved in threshing, winnowing, drying and bagging processes, followed by transportation of grains from field to stores. On-farm losses have also been observed in some developing countries, where growers stake their grains at improper places and wait for rise in market price.

This suggests that there is a huge risk for grain loss right from harvesting to marketing chain systems.
Losses can be minimized by taking care and selecting modern appropriate implements for harvesting at proper time and maturity. Blowing winds, either naturally or created by passing speedy traffic in the case of metal road drying, mainly carry away grains. The breaking of grain kernels has also been considered as one of the major causes of loss observed during drying process of the crop [14]. Grain losses are categorized into: pre-harvest, during harvest and postharvest. The pre-harvest loss occurs before harvesting, harvest loss occurs during the harvesting of the crop and post-harvest loss usually occurs at the time of collection, treatment and threshing. The major grain losses are associated with the specific time and methods of harvesting. The delayed and early harvesting cause shattering of grains which results in lower yield. Post-harvest losses in wheat should be controlled appropriately, because reducing food losses offer an important way of increasing food availability without requiring additional production resources [15]. The crop losses during the process of harvesting, threshing, transportation and storage of food grains are quite significant. It was observed that harvesting losses were more for the late harvested crop due to shattering of the grains, while losses during transportation, handling and rodents attack in the case of stored grains have been found insignificant. Better post-harvest management has resulted in minimum post-harvest losses [16]. To maximize production and cut the dependence on imports of wheat caused authorities to pay special attention to production systems and strategies to increase production and reduce their losses [17]. Keeping in view the above facts, the current study was conducted to assess the wheat yield losses and grain quality of wheat varieties under different methods and time of harvesting and threshing.

\section{MATERIALS AND METHODS}

\subsection{Experimental site and setup}

Factorial field experiments based on Randomized Complete Block Design (RCBD) plot size $3 \times 5 \mathrm{~m}=15$ $\mathrm{m}^{2}$ with 10 treatments and three replications were conducted during 2008-09 and 2009-10 at Latif Experimental Farm Sindh Agriculture University Tandojam to identify losses in wheat grain yield and quality among three bread wheat varieties (Mehran- 
89, TD-1 and Kiran-95) in relation to harvesting time and methods. The experimental soil was Typic Ustochrepts (Sultanpur Series) [18]. It was clay loam in texture, non-saline in nature, $\left(1.3 \mathrm{dS} \mathrm{m}^{-1}\right)$ organic matter $(0.54$ to $.57 \%)$ and available phosphorus (3.00 to3.52 $\mathrm{mg} \mathrm{kg}^{-1}$ ) contents. The soil had adequate enough extractable potassium $\left(160 \mathrm{mg} \mathrm{kg}^{-1}\right)$ for wheat crop.

Recommended seed rate $\left(50 \mathrm{~kg} \mathrm{acre}{ }^{-1}\right)$ of each variety was drilled on 15-11-2008 while maintaining the row to row space of $20 \mathrm{~cm}$. The recommended rates of $\mathrm{N}$, $\mathrm{P}$ and $\mathrm{K}$ (150-80-50 kg ha-1) were applied. Phosphorus in the form of Di-Ammonium Phosphate (DAP) was drilled with seed and fertilizer combined drill as full dose at the time of sowing on $3^{\text {rd }}$ week of November 2008 and 2009.Nitrogen through Urea fertilizer was applied in three equal splits; $1^{\text {st }}$ split was given at the time of sowing in the $3^{\text {rd }}$ week of November 2008/ 2009 , while $2^{\text {nd }}$ split was given with $2^{\text {nd }}$ irrigation on $3^{\text {rd }}$ week of December 2008/2009, and final split was given with $3^{\text {rd }}$ irrigation on $1^{\text {st }}$ week of January $2009 / 2010$.

To overcome weed problem the herbicides (Logran @ $16 \mathrm{~g}+$ Topic $120 \mathrm{~g}$ per acre) were sprayed on $4^{\text {th }}$ week of December $2008 / 2009$. The $4^{\text {th }}, 5^{\text {th }}$ and $6^{\text {th }}$ irrigation was supplied to experiment on $3^{\text {rd }}$ week of January $2009-2010,3^{\text {rd }}$ week of February 2009/2010 and $1^{\text {st }}$ week of March 2009/2010, respectively. Three acre inches water was added during each irrigation event. In total 21 acre inches irrigation water (including soaking dose) was supplied to the experiment. Three hexaploid (bread) wheat varieties (Mehran-89, TD-1, and Kiran-95) were included in the study. The harvesting methods tested in the study were: 1 . Sickle (farmer's practice/ conventional) and 2. Reaper (mechanized). The harvesting times were: wheat crop harvested 5-days-before maturity (DBM), at proper maturity and 05, 10 and 15-days-after maturity (DAM). The experimental plants were harvested on 25-03-2009/2010 for five days before maturity with reaper and sickle, on 31-03-2009/2010 at proper maturity with reaper and sickle, on 6-4-2009/2010 at 5 DAM with reaper and sickle, on 12-04-2009/2010 at 10 DAM with reaper and sickle, and on 18-42009/2010 at 15 DAM with reaper and sickle. The data on losses to grain yield, yield components harvest index (the ratio of grain to straw i.e. $\mathrm{HI}=\underline{\text { Grain }}$ yield/biological yield $\times 100$ and Seed Index $=1000$ grain weight in grams and some grain quality traits (shriveled \& broken grain losses) were recorded.

The meteorological data for wheat growing season for the years of 2008/2009 to 2009/2010 was also collected from Regional Agro Met Center Tando Jam. Accordingly during 2008/2009 the rainfall occurred only during the months of December 2008 to February 2009 which ranged from 0.1 to $0.7 \mathrm{~mm}$. During $2009 / 2010$, rainfall only occurred during the month of January 2010 (1.0 mm). During 2008/2009, the minimum and maximum temperature during November 2008 to April 2009 ranged from 8.5 to 39.0 ${ }^{0} \mathrm{C}$ while during 2009/2010, the minimum and maximum temperature during the crop growth period ranged from 4.5 to $44.0{ }^{\circ} \mathrm{C}$.

The data collected were statistically processed and analyzed, as suggested by Gomez and Gomez) [19], through MSTAT software () Michigan State University USA).The LSD value for mean comparison was calculated for mean comparison at probability $\leq$ 0.05 [19].

\section{RESULTS}

\subsection{Effect of harvesting time and methods on grainyield and yield components in selected wheat varieties}

There was a significant $(p \leq 0.05)$ effect of Harvesting Times (HT) and Harvesting Methods (HM; Table 1), Varieties (V; Table 2) and their interaction (Table- 3) on harvest index, seed index (1000-seed weight) and grain and biological yields of wheat. Compared to various timing treatments, the wheat crop harvested at proper physiological maturity (when dry matter accumulation in kernel or seed ceases and bending of ear-head occurs) displayed maximum value for Harvest Index (HI). In case of harvesting methods tested in the study (Reaper and Sickle), the wheat crop harvested traditionally showed maximum HI values than the mechanical reaper harvested method. The data of Table- 2 showed that the variety TD-1 indicated highest value of $\mathrm{HI}$, followed by Kiran-95 and Mehran-89. Similarly, harvesting time, harvesting methods and varieties showed significant effect on seed index (SI). The Table-2 further revealed that the 
maximum values for SI were observed in variety TD1 in both methods of harvesting (reaper and sickle) at physiological maturity stage, followed by Mehran-89 and Kiran-95. Significant effect of HT, HM and varieties was also noticed on biological and grain yields in this study. Maximum biological and grain yields were recorded in variety Kiran-95 harvested at proper physiological maturity with reaper as compared to other two (Mehran-89 and TD-1) varieties and sickle method included in the study.

Table 1: Effect of harvesting time and methods on some agronomical and yield traits of bread wheat (Mean data of two years 2008-09 \& 2009-10)

\begin{tabular}{|c|c|c|c|c|}
\hline \multirow{2}{*}{$\begin{array}{c}\text { Harvesting } \\
\text { time and } \\
\text { method }\end{array}$} & \multicolumn{4}{|c|}{ Wheat traits } \\
\hline & $\begin{array}{c}\text { Harvest } \\
\text { Index }\end{array}$ & $\begin{array}{l}\text { Seed index } \\
(1000-\text { seed } \\
\text { weight })(\mathrm{g})\end{array}$ & $\begin{array}{c}\text { Biologic } \\
\text { al yield } \\
\left(\mathrm{t} \mathrm{ha}^{-1}\right)\end{array}$ & $\begin{array}{c}\text { Grain } \\
\text { yield } \\
\left(\mathrm{t} \mathrm{ha}^{-1}\right)\end{array}$ \\
\hline $\begin{array}{c}\text { At M with } \\
\text { R }\end{array}$ & $45.25 \mathrm{~b}$ & $47.78 \mathrm{a}$ & $11.63 \mathrm{a}$ & $5.25 \mathrm{a}$ \\
\hline $\begin{array}{l}5 \text { DBM } \\
\text { with R }\end{array}$ & $41.30 \mathrm{j}$ & $40.44 \mathrm{e}$ & $10.66 \mathrm{de}$ & $4.39 \mathrm{e}$ \\
\hline $\begin{array}{l}5 \text { DAM } \\
\text { with } \mathrm{R}\end{array}$ & $44.40 \mathrm{~d}$ & $46.22 \mathrm{~b}$ & $11.5 \mathrm{a}$ & $5.10 \mathrm{ab}$ \\
\hline $\begin{array}{c}10 \text { DAM } \\
\text { with R }\end{array}$ & $43.33 \mathrm{f}$ & $44.44 \mathrm{c}$ & $11.42 \mathrm{ab}$ & $4.94 \mathrm{bc}$ \\
\hline $\begin{array}{c}15 \text { DAM } \\
\text { with } \mathrm{R}\end{array}$ & $42.35 \mathrm{~h}$ & $43.11 \mathrm{~d}$ & $\begin{array}{c}11.37 \\
\mathrm{abc}\end{array}$ & $4.80 \mathrm{~cd}$ \\
\hline $\begin{array}{c}\text { At } M \text { with } \\
\mathrm{S}\end{array}$ & $45.58 \mathrm{a}$ & $47.78 \mathrm{a}$ & $\begin{array}{c}11.35 \\
\mathrm{abc}\end{array}$ & $5.16 \mathrm{a}$ \\
\hline $\begin{array}{l}5 \text { DBM } \\
\text { with S }\end{array}$ & $41.62 \mathrm{i}$ & $40.78 \mathrm{e}$ & $10.30 \mathrm{e}$ & $4.27 \mathrm{e}$ \\
\hline $\begin{array}{l}5 \text { DAM } \\
\text { with S }\end{array}$ & $44.78 \mathrm{c}$ & $46.00 \mathrm{~b}$ & $\begin{array}{c}10.99 \\
\text { bcd }\end{array}$ & $4.91 \mathrm{bc}$ \\
\hline $\begin{array}{l}10 \text { DAM } \\
\text { with S }\end{array}$ & $43.64 \mathrm{e}$ & $44.00 \mathrm{c}$ & $10.94 \mathrm{~cd}$ & $4.76 \mathrm{~cd}$ \\
\hline $\begin{array}{c}15 \text { DAM } \\
\text { with S }\end{array}$ & $42.75 \mathrm{~g}$ & $42.78 \mathrm{~d}$ & $10.88 \mathrm{~d}$ & $4.63 \mathrm{~d}$ \\
\hline SE & 0.0226 & 0.2644 & 0.1509 & $\begin{array}{c}0.0674 \\
9\end{array}$ \\
\hline LSD (5\%) & 0.0633 & 0.7484 & 0.4272 & 0.1911 \\
\hline
\end{tabular}

$\mathrm{M}=$ Maturity, $\mathrm{R}=$ Reaper, DBM = Days Before Maturity, DAM = Days After Maturity, $\mathrm{S}=$ Sickle.

Table 2: Varietal variability for some yield, traits (mean data of two years 2008-09 \& 2009-10)

\begin{tabular}{|c|c|c|c|c|c|}
\hline \multirow{2}{*}{$\begin{array}{l}\text { Wheat } \\
\text { traits }\end{array}$} & \multicolumn{5}{|c|}{ Wheat varieties } \\
\hline & $\begin{array}{c}\text { Mehran } \\
-89\end{array}$ & TD-1 & $\begin{array}{c}\text { Kiran- } \\
95\end{array}$ & SE & $\begin{array}{l}\text { LSD } \\
(5 \%)\end{array}$ \\
\hline $\begin{array}{l}\text { Harvest } \\
\text { Index }\end{array}$ & $42.28 \mathrm{c}$ & $\begin{array}{c}45.57 \\
\mathrm{a}\end{array}$ & $\begin{array}{c}42.65 \\
\text { b }\end{array}$ & 0.02236 & 0.06330 \\
\hline $\begin{array}{l}\text { Seed } \\
\text { index } \\
\text { (g) }\end{array}$ & $43.10 \mathrm{~b}$ & $\begin{array}{c}47.43 \\
\mathrm{a}\end{array}$ & $\begin{array}{c}42.47 \\
\mathrm{c}\end{array}$ & 0.1448 & 0.4099 \\
\hline $\begin{array}{l}\text { Biologic } \\
\text { al yield } \\
\left(\text { ton } \mathrm{ha}^{-1}\right)\end{array}$ & $11.67 \mathrm{a}$ & $\begin{array}{c}9.765 \\
\text { b }\end{array}$ & $\begin{array}{c}11.88 \\
\mathrm{a}\end{array}$ & 0.08266 & 0.2340 \\
\hline $\begin{array}{l}\text { Grain } \\
\text { yield } \\
\left(\text { ton } \mathrm{ha}^{-1}\right)\end{array}$ & $4.94 \mathrm{~b}$ & $4.45 \mathrm{c}$ & $\begin{array}{c}5.073 \\
\mathrm{a}\end{array}$ & 0.03697 & 0.1047 \\
\hline
\end{tabular}

3.2 Estimation of losses to grain yield and qualitycaused by time and method of harvest in wheat cultivars

The data given in Fig.1 indicates that there was significant $(\mathrm{P} \leq 0.05)$ effect of HT.

Table 3: Interactive effect of wheat cultivars $X$ Harvesting time and method on yield traits

\begin{tabular}{|c|c|c|c|c|}
\hline \multirow{2}{*}{$\begin{array}{l}\text { Varieties } \mathrm{x} \\
\text { harvesting } \\
\text { time and } \\
\text { method }\end{array}$} & \multicolumn{4}{|c|}{ Wheat traits } \\
\hline & $\begin{array}{l}\text { Harvest } \\
\text { Index }\end{array}$ & $\begin{array}{l}\text { Seed } \\
\text { index } \\
(\mathrm{g})\end{array}$ & $\begin{array}{l}\text { Biological } \\
\text { yield } \\
\left(\mathrm{t} \mathrm{ha}^{-1}\right)\end{array}$ & $\begin{array}{l}\text { Grain } \\
\text { yield } \\
\left(\mathrm{t} \mathrm{ha}^{-1}\right)\end{array}$ \\
\hline $\begin{array}{c}\text { At M with } \\
\text { R }\end{array}$ & $47.12 \mathrm{~b}$ & $51.33 \mathrm{a}$ & $10.37 \mathrm{fgh}$ & $\begin{array}{l}4.89 \\
\text { defghi }\end{array}$ \\
\hline $\begin{array}{l}5 \mathrm{DBM} \\
\text { with R }\end{array}$ & $43.58 \mathrm{k}$ & $43.33 \mathrm{gh}$ & $9.49 \mathrm{ijk}$ & 4.14 op \\
\hline $\begin{array}{l}5 \text { DAM } \\
\text { with R }\end{array}$ & $46.24 \mathrm{~d}$ & $48.67 \mathrm{~b}$ & 10.25 ghi & $\begin{array}{l}4.74 \\
\text { ghijkl }\end{array}$ \\
\hline $\begin{array}{c}10 \text { DAM } \\
\text { with R }\end{array}$ & $45.52 \mathrm{e}$ & $47.33 \mathrm{c}$ & 10.19 ghi & $\begin{array}{l}4.64 \\
\text { hijklm } \\
\end{array}$ \\
\hline $\begin{array}{c}15 \text { DAM } \\
\text { with R }\end{array}$ & $44.47 \mathrm{~h}$ & $\begin{array}{l}46.00 \\
\text { cde }\end{array}$ & $10.11 \mathrm{hij}$ & $\begin{array}{l}4.50 \\
\text { jklmno }\end{array}$ \\
\hline $\begin{array}{c}\text { At } M \text { with } \\
\mathrm{S}\end{array}$ & $47.33 \mathrm{a}$ & $51.33 \mathrm{a}$ & 10.26 ghi & $\begin{array}{l}4.86 \\
\text { efghij }\end{array}$ \\
\hline $\begin{array}{l}5 \text { DBM } \\
\text { with } S\end{array}$ & $43.93 \mathrm{ij}$ & $43.33 \mathrm{gh}$ & $9.12 \mathrm{k}$ & $4.01 \mathrm{p}$ \\
\hline $\begin{array}{l}5 \text { DAM } \\
\text { with } S\end{array}$ & $46.84 \mathrm{c}$ & $49.33 \mathrm{~b}$ & $9.34 \mathrm{jk}$ & $\begin{array}{l}4.371 \\
\text { mnop }\end{array}$ \\
\hline $\begin{array}{l}10 \text { DAM } \\
\text { with S }\end{array}$ & $45.70 \mathrm{e}$ & $47.33 \mathrm{c}$ & $9.28 \mathrm{k}$ & 4.24 nop \\
\hline $\begin{array}{c}15 \text { DAM } \\
\text { with } S\end{array}$ & $44.93 \mathrm{f}$ & $46.33 \mathrm{~cd}$ & $9.20 \mathrm{k}$ & 4.14 op \\
\hline SE & 0.07071 & 0.4579 & 0.2614 & 0.1169 \\
\hline LSD 5\% & 0.2002 & 1.296 & 0.7400 & 0.3309 \\
\hline
\end{tabular}

R: Reaper; S: Sickle; DBM: Days before maturity, DAM: Days after maturity

harvesting methods (HM), varieties (V) and their interaction (Table-4) on harvest, hauling and Fig. 2 broken losses \% recorded for yield and quality of wheat grains. The data given in the Table-4 reveal that the maximum harvest and hauling losses percentage was found at 15 days after maturity with sickle a traditional method of harvesting in variety TD-1, followed by Mehran-89 and Kiran-95. However, the minimum losses percentage was recorded in variety Kiran-95 at proper physiological maturity with modern/ mechanized reaper method of harvesting. The data in Figure-2 for broken losses percentage showed that the higher broken losses percentage was observed when wheat crop was threshed at 8.00 am as compared to 12.00 noon and $7.00 \mathrm{pm}$ and minimum losses percentage was recorded when the wheat crop was threshed at 12.00 noon. In case of varietal response to broken grain losses, the data in Figure-3 displayed that the maximum broken losses percentage was recorded 
in variety Kiran-95, followed by TD-1 and Mehran-89 variety.

Table 4: Interactive effect of wheat varieties $X$ harvesting time and method on wheat harvest and hauling losses traits (mean data of two years 2008-09 \& 2009-10)

\begin{tabular}{|c|c|c|c|c|}
\hline \multirow[b]{2}{*}{$\begin{array}{c}\text { Varieties } \\
x \\
\text { harvestin } \\
\text { g time } \\
\text { and } \\
\text { method }\end{array}$} & \multicolumn{4}{|c|}{ Wheat traits } \\
\hline & $\begin{array}{c}\text { Harvestin } \\
\mathrm{g} \mathrm{losses} \\
\left(\mathrm{kg} \mathrm{ha}^{-1}\right)\end{array}$ & $\begin{array}{l}\text { Harvesting } \\
\text { Losses (\%) }\end{array}$ & $\begin{array}{c}\text { Hauling } \\
\text { losses } \\
\left(\mathrm{kg} \mathrm{ha}^{-1}\right)\end{array}$ & $\begin{array}{c}\text { Hauling } \\
\text { Losses } \\
(\%)\end{array}$ \\
\hline $\begin{array}{l}\text { At M } \\
\text { with R }\end{array}$ & $261.3 \mathrm{fgh}$ & $5.357 \mathrm{hij}$ & $419.3 \mathrm{gh}$ & $8.57 \mathrm{gh}$ \\
\hline $\begin{array}{l}5 \mathrm{DBM} \\
\text { with } \mathrm{R}\end{array}$ & 251.7 ghi & $6.090 \mathrm{f}$ & $409.3 \mathrm{~h}$ & $9.89 \mathrm{~d}$ \\
\hline $\begin{array}{l}5 \mathrm{DAM} \\
\text { with } \mathrm{R}\end{array}$ & $295.0 \mathrm{def}$ & $6.213 \mathrm{f}$ & $\begin{array}{l}451.7 \\
\text { def }\end{array}$ & $9.54 \mathrm{e}$ \\
\hline $\begin{array}{l}10 \text { DAM } \\
\text { with } R\end{array}$ & $328.3 \mathrm{bc}$ & $7.070 \mathrm{~d}$ & $485.0 \mathrm{bc}$ & $10.45 \mathrm{c}$ \\
\hline $\begin{array}{l}15 \mathrm{DAM} \\
\text { with } \mathrm{R}\end{array}$ & $382.3 \mathrm{a}$ & $8.490 \mathrm{~b}$ & $539.0 \mathrm{a}$ & $11.99 \mathrm{~b}$ \\
\hline $\begin{array}{l}\text { At M } \\
\text { with S }\end{array}$ & $\begin{array}{l}270.0 \\
\text { efgh }\end{array}$ & $5.557 \mathrm{gh}$ & $\begin{array}{l}427.7 \\
\text { fgh }\end{array}$ & $8.79 \mathrm{fg}$ \\
\hline $\begin{array}{l}5 \text { DBM } \\
\text { with } S\end{array}$ & $262.0 \mathrm{fgh}$ & $6.540 \mathrm{e}$ & $419.0 \mathrm{gh}$ & $10.46 \mathrm{c}$ \\
\hline $\begin{array}{l}5 \text { DAM } \\
\text { with S }\end{array}$ & $310.3 \mathrm{bcd}$ & $7.093 \mathrm{~d}$ & $467.3 \mathrm{~cd}$ & $10.67 \mathrm{c}$ \\
\hline $\begin{array}{l}10 \text { DAM } \\
\text { with } S\end{array}$ & $343.0 \mathrm{~b}$ & $8.063 \mathrm{c}$ & $499.3 \mathrm{~b}$ & $11.76 \mathrm{~b}$ \\
\hline $\begin{array}{l}15 \text { DAM } \\
\text { with } S\end{array}$ & $391.0 \mathrm{a}$ & $9.450 \mathrm{a}$ & $548.0 \mathrm{a}$ & $13.25 \mathrm{a}$ \\
\hline SE & 10.48 & 0.1065 & 8.349 & 0.1065 \\
\hline $\begin{array}{l}\text { LSD } \\
(5 \%) \\
\end{array}$ & 29.66 & 0.3014 & 23.63 & 0.3014 \\
\hline
\end{tabular}

$\mathrm{M}=$ Maturity, $\mathrm{R}=$ Reaper, $\mathrm{DBM}=$ Days before maturity, DAM = Days after maturity, $\mathrm{S}=$ sickle

\section{DISCUSSION}

Rapid rise in World's population seems to be a challenge for agriculturists to feed through boosting crop yields by reducing crop inputs as well as reducing postharvest losses [1]. Reducing postharvest losses allow farmers to keep more of their crop and increase grain supplies, which are critical in a world where resources are scarce and rural developing economies struggle [20]. Keeping in view minimizing postharvest losses, present study was conducted to enhance yield goals through proper postharvest measures. Already, it has been estimated that food loss could be equivalent to $6-10 \%$ due to of men made agricultural practices by generated greenhouse gas emissions [21-23] responsible for raising the global warming and causing abrupt change in climate. Similarly, the area under study was observed hot in the months of April and
May so the more harvest, hauling and grain shattering losses were recorded. Furthermore it has been estimated that $25 \%$ reduction in yield occurs due to postharvest losses of food grains in developing countries [24]. In rice, about 15 to $16 \%$ postharvest loss has been estimated. This shows that one-quarter of cereals is produced never reaches the consumer for whom it was grown, and the effort and money required to produce it are lost-forever.

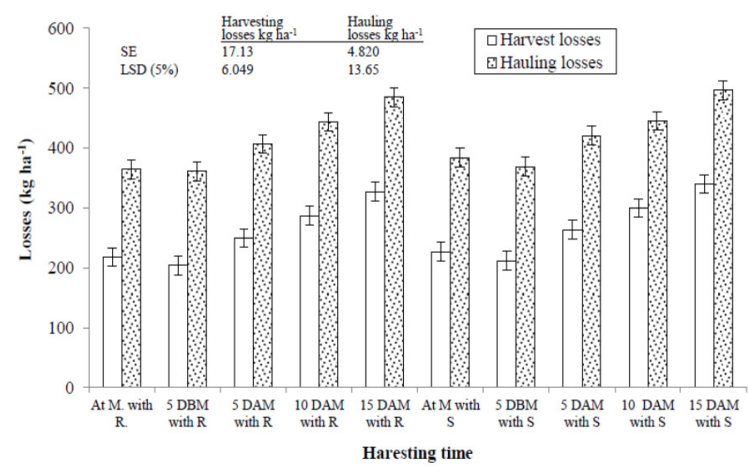

Fig. 1: Effect of Wheat Harvesting Time and Method on Harvest and Hauling Losses (\%)

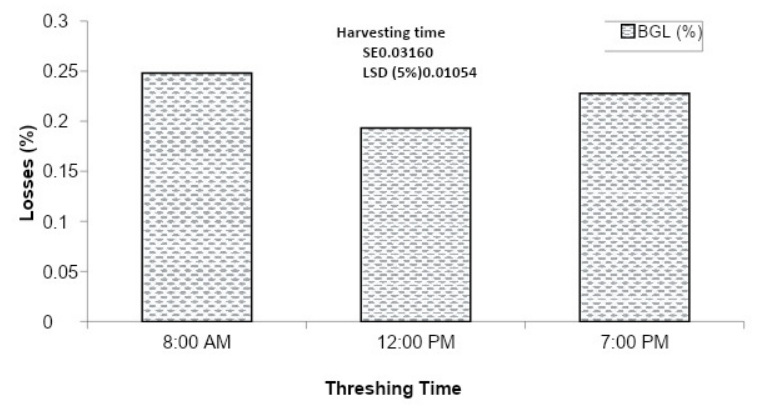

Fig. 2: Effect of Different Threshing Time on Broken Grain Losses in Weight (\%)

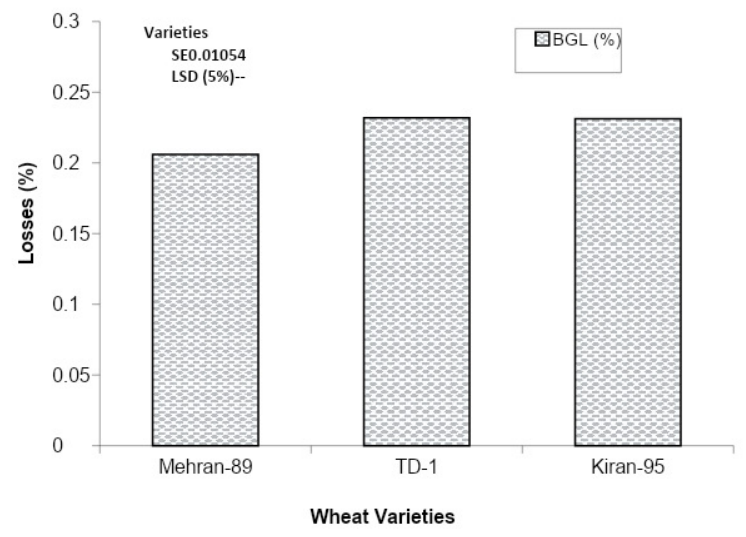

Fig. 3: Wheat varietal variation against Broken Grain Losses (\%) 
The accurate estimates of production loss are hard to judge. With regard to wheat postharvest losses, no proper estimates have been worked out yet, thus, this study is much more informative to monitor and estimate postharvest losses in wheat. Harvesting crop too early or late especially in wheat influences grain filling and grain shattering, respectively which ultimately causes yield loss. The loss in grain yield has been attributed to various yield components i.e. grains per spike, spike number, spike length and harvest if crop is improperly harvested before maturity. Regarding harvesting method, if the crop is fully matured, the harvesting through reaper and sickle has more grains loss in terms of grain shattering in the field. Comparison between reaper and sickle was done by [25]. They observed about 6 to $12 \%$ harvesting losses with reaper. Furthermore, if manual harvesting is delayed due to a lack of labor, then losses would be incurred due to shattering of overripe grains.

In this study, we observed reduction in losses to grain yield and yield components associated to harvest of crop 5 days before grain maturity. Furthermore, delay in harvest contributed grain loss of 3\% and 7\%; when harvesting was delayed for a week and three weeks, respectively. Delay in crop harvest showed negative impact on spikes. Particularly the spikelets become loose after drying and grains fall down on the ground due to wind or improper crop harvesting method especially with manual harvesting [26]. Grain loss of over matured wheat crop with manual harvesting up to $7 \%$ was also observed [25].

In order to minimize the shattering losses and avoid delay in sowing the next crop, the standing wheat crop should be harvested in a short possible time after attaining full maturity. Among the various factors, the main reason for wheat grain loss is the field shattering due to over crop maturity. The delay in wheat crop harvesting for one week has no significant effect on the grain shattering or grain yield. The natural hazards including rain, windstorm, hailstones, etc. encourage grain losses at harvesting stage [27]. Therefore, use of reaper plus thresher or combine harvester minimizes the risk of grain losses by winding up the process of harvesting and threshing by avoiding the natural hazards. However, grain yield significantly reduces, if the harvesting was delayed for 15 days after attaining maturity. Similarly, chickpea crop has shown reduction in yield by $6.97 \%$, mainly due to postharvest losses, especially over crop maturity and delay in harvesting as reported by Nag et al. [28]. Thus, this study is in agreement with the findings of other researchers who found satisfactory yield targets due to proper harvesting times.

\section{CONCLUSION}

It can be concluded from the study that losses to wheat grain quality and yield depend on the time and method of harvest and varieties. In this study, minimum postharvest losses to grain quality and yield were observed when the wheat crop was harvested with reaper at proper physiological maturity stage, as compared to early and late harvest with conventional (manual) method. Among the three varieties included in the study minimum postharvest losses and maximum grain yield were displayed by Kiran-95, followed by Mehran-89 and TD -1.

\section{ACKNOWLEDGEMENT}

The authors are thankful to the Director Farms, for permission to conduct the field experiments at Latif Experimental Farm, Sindh Agriculture University, Tandojam. The authors are also thankful to central Analytical Laboratory Agriculture Chemistry Soil Fertility Section, Agriculture Research Institute, Tandojam for testing the soil samples of experiment and thankful to Nuclear Institute of Agriculture (NIA) Tandojam for providing the facility of reaper and confirmation of losses in their wheat field experimental area.

\section{REFERENCES}

[1] UN., Save food global initiative on food losses and waste reduction, FAO. Available at: http://www.fao. org/save-food/keyfindings/en/, 2013.

[2] Goldsmith, P.D., Martins, A.G., and de Moura, A.D., "The economics of postharvest loss: a case study of the new large soybean-maize producers in tropical Brazil", Food Security, Vol. 7, No. 4, pp. 875-888, 2015. 
[3] Minten, B., Engida, E., and Tamru, S., "How big are post-harvest losses in Ethiopia? Evidence from teff'. International Food Policy Research Institute, Vol. 93, No. 1, pp. 1-10, 2016.

[4] Parfitt, J., Barthel, M., and McNaughton, S., "Food waste within food supply chains: quantification and potential for change to 2050", Philosophical Transactions of the Royal Society of London B: Biological Sciences, Vol. 365, No. 1554, pp. 3065-3081, 2010.

[5] Prusky, D., "Reduction of the incidence of postharvest quality losses, and future prospects", Food Security, Vol. 3, No. 4, pp. 463-474, 2011.

[6] An, K., and Ouyang. Y., "Robust grain supply chain design considering post-harvest loss and harvest timing equilibrium", Transportation Research Part E: Logistics and Transportation Review, Vol. 88, No. 2, pp. 110-128, 2016.

[7] Shende, K.S., and Lifeter Y.B., "Post-harvest challenges of food crops in Jakairi subdivision, Cameroon-A threat to food security", Saudi Journal of Humanities and Social Sciences, Vol. 2, No. 10, pp. 974-983, 2017.

[8] Trostle, R., "Global Agricultural Supply and Demand: Factors Contributing to the Recent Increase in Food Commodity Prices", URL : https://www.ers.usda.gov/webdocs/publicati ons/40463/12274_wrs0801_1_.pdf?v=0/ 2008.

[9] The World Bank., "Missing Food: The case of postharvest grain losses in Sub-Saharan Africa", 2011.

[10] Bruinsma, J., "World Agriculture: towards 2015/2030", Food and Agriculture Organization of the United Nations, Rome, 2003.

[11] Alexandratos N., and Bruinsma, J., "World agriculture towards 2030/2050", Food and Agriculture Organization of the United Nations Nations, Rome, 2012.

[12] Gibson, L., and Benson, G., "Origin, history, and uses of oat (Avena sativa) and wheat
(Triticum aestivum L.)", Iowa State University, Department of Agronomy, 2002.

[13] Basavaraja, H., Mahajanashetti, S.B., and Udagatti, N.C., "Economic analysis of postharvest losses in food grains in India: a case study of Karnataka", Agricultural Economics Research Review, Vol. 20, No. 1, pp. 117126, 2007.

[14] Harris, K.L., and Lindblad, C.J., "PostHarvest Grain Loss Assessment Methods: A Manual of Methods for the Evaluation of Postharvest Losses", American Association of Cereal Chemists, USA, pp. 695- 670, 1976.

[15] Hodges, R., Hodges, J., Buzby, J.C., and Bennett, B., "Postharvest losses and waste in developed and less developed countries: Opportunities to improve resource use", Journal of Agricultural Science, Vol. 149, No. 1, pp. 37-45, 2011.

[16] Grover, D.K., and Singh, J.M., "Post-harvest losses in wheat crop in Punjab: Past and Present”, Agricultural Economics Research Review, Vol. 26, No. 2, pp. 70-76, 2013.

[17] Jamshidi, A.R., and Afrous, A., "Wheat harvest losses forecast and data analysis using dummy variables model", Saudi Journal of Humanities and Social Sciences, Vol. 2, No. 10, pp. 974-983, 2017.

[18] Rafiq, Ch. M., "Soil series key and systematic classification of soils, (West Pakistan), Soil survey project of Pakistan, Lahore", 1970.

[19] Gomez and Gomez., "Statistical Procedures for Agricultural Research", John Wiley \& Sons, 1984.

[20] Tefera, T., Mugo, S., and Beyene, Y., "Developing and deploying insect resistant maize varieties to reduce pre and post-harvest food losses in Africa", Food Security, Vol. 8, No. 1, pp. 211-220, 2016.

[21] Gustavsson, J., Cederberg, C., Sonesson, U., van Otterdijk, R., and Meybeck. "Global Food Losses and Food Waste: Extent Causes and Prevention", Food and Agriculture Organization of the United Nations, Rome, Italy, 2011, 
URL:http://www.madr.ro/docs/indalimentar a/risipa_alimentara/presentation food_waste.pdf/.

[22] Vermeulen, S.J., Aggarwal, P.K., Ainslie, A., Angelone, C., Campbell, B. M., Challinor, A.J., Hansen, J.W., Ingram, J.S.I., Jarvis, A., Kristjanson, P., Lau, C., Nelson, G.C., Thornton, P.K., and Wollenberg, E., "Options for support to agriculture and food security under climate change", Environmental Science and Policy, Vol. 15, pp. 136-144, 2012.

[23] Guo, P.P., Li, P.L., Li, Z.C., Stein, H.H., Liu, L., Xia, T., and Ma, Y. X., "Effects of Postharvest Storage Duration and Variety on Nutrient Digestibility and Energy Content Wheat in Finishing Pigs", AsianAustralasian Journal of Animal Sciences, Vol. 28, No. 10, pp. 1488, 2015.

[24] Food and Agriculture Organization, "Estimated Post-Harvest Losses of Rice in Southeast Asia", 1997, URL: http://www.fao.org/News/Factfile/FF9712E. $\mathrm{htm} /$.

[25] Sukhbir, S., Vatsa, D.K., and Verma, M.K., "Feasibility and performance evaluation of power tiller operated reaper in hills of Himachal Pradesh", Agricultural Engineering Today, Vol. 31, No. 2, pp. 6-10, 2007.
[26] Iqbal, M., Sheikh, G.S., and Sial, J.K., "Harvesting and threshing losses of wheat with mechanical and conventional methods", Agricultural Mechanization in Asia (Japan), Vol. 11, No. 3, pp. 66-70, 1980.

[27] Muhammad, S., Mueen-u-Din, Mushtaq, A., Liaqat, A., Masood, W.Q., Muhammad, A.A., and Laila, K., "Grain Losses of Wheat as Affected by Different Harvesting and Threshing Techniques", International Journal of Research in Agricultural and Forestry, Vol. 2, No. 6, pp. 20-26, 2015.

[28] Nag, S.K., Nahatkar, S.B., Sharma, H.O., Post-harvest losses of chickpea as perceived by the producers of Sehore District of Madhya Pradesh", Agricultural Marketing, Vol. 43 No. 3 pp. 12-16, 2000 